\title{
Acknowledgements and Dedication
}

A great store of debts has been built up in the decade since Roger Mason first asked me to write this volume. First, to Roger himself for giving me that opportunity, bearing with me through the upheavals which delayed its appearance, and then asking me to cut only 35,000 words from the text! Next to the commissioning editors and all the staff at EUP, past and present, who have steered the book to its conclusion. To Alex Woolf, for his insightful reading of drafts chapters and for long discussions on the more esoteric issues of twelfth-century Scottish history during many trips up Scottish mountains, and to Dauvit Broun for his ever-generous sharing of ideas; you will see your fingerprints on many pages! A host of thanks is owed to my colleagues Alasdair Ross and Michael Penman, who read and commented upon the text, but remained unscarred by the process. All of Peter Lynch's helpful advice has been studiously ignored, but he does now know what a davoch is! To my children, Alasdair and Lauren, who have literally grown up with this monster, I dedicate this book to you.

Crieff

St Andrew's Day 2010 